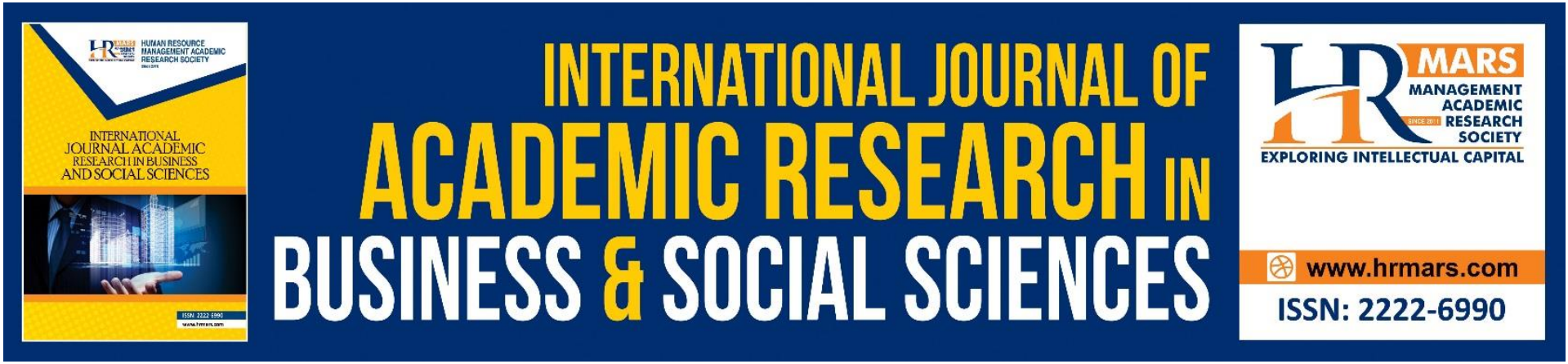

\title{
Online Consumers Buyer Behavior - Post Covid-19
}

Nur Faithzah Jamian, Azlin Zanariah Bahtar, Zamzuri Ahmad Nazari, Nurazree Mahmud, Rizuwan Abu Karim, Hilda Monoarfa

To Link this Article: http://dx.doi.org/10.6007/IJARBSS/v11-i11/11571 DOI:10.6007/IJARBSS/v11-i11/11571

Received: 05 September 2021, Revised: 02 October 2021, Accepted: 26 October 2021

Published Online: 12 November 2021

In-Text Citation: (Jamian et al., 2021)

To Cite this Article: Jamian, N. F., Bahtar, A. Z., Nazari, Z. A., Mahmud, N., Karim, R. A., \& Monoarfa, H. (2021). Online Consumers Buyer Behavior - Post Covid-19. International Journal of Academic Research in Business and Social Sciences, 11(11), $830-841$.

Copyright: (c) 2021 The Author(s)

Published by Human Resource Management Academic Research Society (www.hrmars.com)

This article is published under the Creative Commons Attribution (CC BY 4.0) license. Anyone may reproduce, distribute, translate and create derivative works of this article (for both commercial and non-commercial purposes), subject to full attribution to the original publication and authors. The full terms of this license may be seen at: http://creativecommons.org/licences/by/4.0/legalcode

Vol. 11, No. 11, 2021, Pg. $830-841$

Full Terms \& Conditions of access and use can be found at http://hrmars.com/index.php/pages/detail/publication-ethics 


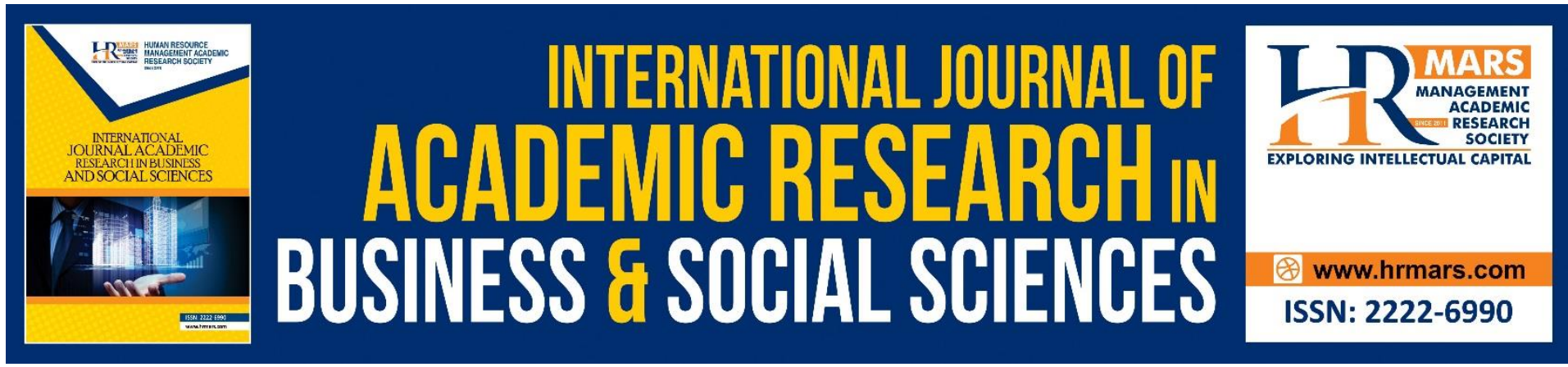

\title{
Online Consumers Buyer Behavior - Post Covid-19
}

\author{
Nur Faithzah Jamian, Azlin Zanariah Bahtar, Zamzuri Ahmad \\ Nazari, Nurazree Mahmud, Rizuwan Abu Karim, Hilda \\ Monoarfa
}

Universiti Teknologi MARA Melaka, Malaysia Universitas Pendidikan Indonesia Email: faithzah@uitm.edu.my

\begin{abstract}
Consumer buying behavior has changed prior to the new environments that lead by pandemic of Covid-19. Many studies have been conducted to examine the changes of consumer buying behavior on the usage of technology as a tool to support online business amid this pandemic. However, there are little studies directed on examining the changes of consumer patterns in online business after the end of Restriction of Movement Order (RMO) in Malaysia. Hence, this study intends to describe the trends of consumer behavior in Malaysia conducting business purchase via online platform pre and post restriction movement order in Malaysia. In order to track these changes, 187 responses were gathered by using online survey and targeted to the different demographic profile of respondents. Given the post RMO, most of the respondents intend to use online platform to buy certain products due to its convenience, time saving, accessibility and safety concern with the aim to minimize risk of spreading the virus. The categories of products consumer purchased via online also identified in this study and the finding reveals certain categories of products having continuously increasing even before, during and 12 months after RMO.
\end{abstract}

Keywords: Consumer Behavior, Covid-19, Online Purchasing, Online Payment Methods

\section{Introduction}

When Malaysians expected the year of 2020 to be the most prosperous year, the most unexpected thing struck not only in Malaysia, but the entire world. The outbreak of coronavirus (Covid-19) started slightly before December 2019 in Wuhan, China and the first case was detected in Malaysia on January $24^{\text {th }}, 2020$ (WHO, 2020). The figures kept on increasing and has forced the Malaysian government to take a serious action by announcing the Restriction of Movement Order (RMO) that started on March $18^{\text {th }}, 2020$. This order enforced under the Control and Prevention of Infectious Diseases Act 1988 and the Police Act 1967 (PMO, 2020).

This pandemic has caused a declining in the growth of the world's economy and has affected the social and economic balance in all affected countries including Malaysia and it concerns all (Standish \& Bossi, 2020; Zierlein et al., 2020). From the execution of RMO, both large and small medium enterprises (SME) in Malaysia had restructured their business modeling and have changed their method of interaction and conducting businesses from offline to online. 
These changes are viewed as necessary to both sellers and purchasers (Wold, 2020; Zierlein et al., 2020). Without the online presence, sellers may not able to run their businesses. Moreover, purchasing via digital platform is viewed to be the safest shopping act that consumers could conduct during the pandemic days (Pastore, 2020; Tam, 2020; Tucker, 2020; Wold, 2020).

Countless changes have been made since the announcement of the RMO. Many business sectors including food and beverages, tourism industry, entertainment businesses are allowed to start operating as usual to facilitate the redevelopment of the nation's economy. Although that, people are still uncomfortable to visit public places to avoid big crowds (Arora et al., 2020; Pastore, 2020). Thus, the purchasing behavior are expected will not go back to pre Covid-19, and the behavior developed within the past five months is probably will remain (Pastore, 2020). By now, retailers and business operators should have known that the whole market pattern has changed (Standish \& Bossi, 2020; Tam, 2020: Wold, 2020).

Prior to this disastrous event, the business operators, retailers and sellers had experienced many disruptions and changes. Yet, nothing has really made the consumption patterns to shift drastically and massively (Zierlein et al., 2020). Few studies had been conducted in the Europe and North America revealed consumers may continue to purchase via online platforms as they already comfortable in doing so and still feel reluctant to be in open spaces for purchasing (Arora et al., 2020; Pastore, 2020; Standish \& Bossi, 2020; Tam, 2020; Wold, 2020; Zierlein et al., 2020). Therefore, the purpose of this study is to describe the behavior of Malaysian consumers towards online consumption after more than 12 months of RMO.

\section{Literature Review}

Online purchasing is not new in Malaysia especially after the great amount of innovations of smartphones, and the increasing rate of smartphone penetration (Bahtar, 2019; Tham, Dastane, Johari, \& Ismail, 2019). Due to that, digital commerce or eCommerce market has evolved and grown considerably positively for the past few years (Zierlein et al., 2020) and this pandemic situation definitely makes buying via digital platform be even more accepted. More and more consumers regardless of locations and generations have started to adapt and accept this new norm on getting their products from digital platforms (Pastore, 2020; Standish \& Bossi, 2020; Tucker, 2020; Wold, 2020).

Sale on several products such as disposable gloves, cough and cold, bread machine, soups, dried grains and rice, packaged food, fruits cups, weight training, milk and cream, dishwashing supplies, paper towel, hand soaps and sanitizer, pasta, vegetables, flour, facial tissues and allergy medicine increase tremendously during Restriction of Movement (RMO). On the other hand, the products that declines during Covid-19 are luggage and suitcase, briefcase, cameras, men's swimwear, women swimwear, bridle dress, men formal dress, gym bags, rash guards, boys, athletic shoes, toys, lunch boxes, wallets, watches, girl's jackets and coats, boy's top's and caps (Andrienko, 2020). Moreover, retail sales of e-commerce show that Covid-19 has significant impact on e-commerce and its sales are expected to reach USD\$6.5 trillion by 2023 (Jones, 2020).

Previous studies on behavioral studies during a pandemic, had shown that an epidemic or pandemic outbreak can cause panic buying among consumers (Jung et al., 2016; Shyam \& 
Abirami, 2020). Although the Malaysian government has consistently addressed the nation with reminders not to panic and with assurance that there are sufficient daily necessities, especially food; the various postings about long queues and empty shelves in supermarkets continued to circulate on social media causing panic among Malaysian consumers. (Roy et al., 2020).

Before Covid-19, toiletries, pharmaceuticals, cosmetics and services like finance, investment and industry are among products purchased by Malaysian consumers through online (MCMC, 2017). But, due to pandemic Covid-19 the consumer has shifted to the online store to purchase products/services. The pandemic has significantly accelerated the adoption of ecommerce worldwide. The pandemic has accelerated the shift towards a more digital world and triggered changes in online shopping behaviors that are likely to have lasting effects (United Nations, 2020). According to a survey conducted by Rakuten Insight, 34 percent of respondents stated they made more online purchases online during the pandemic (Statista, 2020). Similar study stated that $73 \%$ of Malaysians said that the outbreak of the Covid-19 pandemic has made them more positive about online shopping (Syahirah, 2020). As a result of the changes in online consumer behavior towards online shopping, the retailer needs to keep abreast of those changes.

\section{Methodology}

The survey of this study is for Malaysia consumers who have experiences in conducting purchasing during the pandemic Covid-19 via online digital platform. The main aim of this study is to describe the possible purchasing behavior of consumers after more than 12 months we have endured the phases of RMO. In order to maximize a response rate, convenience sampling technique was employed where the link to this survey was blast and shared on main social media platforms (Facebook, Instagram, and WhatsApp). To maintain external validity, data is sampled from various groups to cover as many demographic backgrounds to ensure that the samples were representative and unbiased. The data collection process lasted for 3 weeks. A total of 187 surveys were obtained and table 1 below summarizes the demographic of the respondents. 


\section{Results and Discussion}

Table 1: Demographic Profile

\begin{tabular}{|c|c|c|}
\hline Demographic & $\begin{array}{r}\text { Fre } \\
\text { quency }\end{array}$ & Percent \\
\hline \multicolumn{3}{|r|}{ Age } \\
\hline $18-21$ & 4 & 1.92 \\
\hline $22-25$ & 39 & 20.9 \\
\hline $26-30$ & 27 & 14.4 \\
\hline $31-35$ & 54 & 28.9 \\
\hline $36-40$ & 25 & 13.4 \\
\hline $41-45$ & 24 & 12.8 \\
\hline $46-50$ & 7 & 3.84 \\
\hline Above 50 & 7 & 3.84 \\
\hline \multicolumn{3}{|r|}{ Gender } \\
\hline Male & 42 & 22.5 \\
\hline Female & 145 & $\mathbf{7 7 . 5}$ \\
\hline \multicolumn{3}{|c|}{ Occupation } \\
\hline Public/Government & 42 & 22.5 \\
\hline $\begin{array}{r}\text { Private } \\
\end{array}$ & 63 & 33.7 \\
\hline Self Employed & 27 & 14.4 \\
\hline Student & 35 & 18.7 \\
\hline Unemployed & 13 & 7.0 \\
\hline Freelance & 6 & 3.0 \\
\hline Others & 1 & 0.7 \\
\hline \multicolumn{3}{|c|}{ Neighborhood Area } \\
\hline Urban (City Area) & 67 & 35.8 \\
\hline $\begin{array}{rr}\text { SubUrban } & \text { (Housing } \\
& \text { Area) } \\
\end{array}$ & 107 & 57.2 \\
\hline Rural (Village Area) & 13 & 7.0 \\
\hline
\end{tabular}

In this study, questions related to the demographic profile of the respondents are included in Section $C$ of the questionnaire. There are four questions which cover age, gender, occupation, and neighbourhood area. As summarized in Table 1, the total of 187 respondents ranged from age of 18 years old to late 50s. The respondents consisted of 145 female (77.5 per cent) and 42 male ( 22.5 per cent) whom were responded to the surveys. From 187 respondents, 7.0 per cent are unemployed, 18.7 per cent are students and 74.3 per cent of the respondents are working in several sectors. A majority of respondents $(57.2$ per cent) lives in suburban (housing area), 35.8 per cent in urban (city area) and about 7.0 per cent lives in rural (village area). 
Table 2: Category/Type of Products Consumers Purchased Via Online Before RMO

\begin{tabular}{|r|r|c|}
\hline $\begin{array}{l}\text { Category/Type of Products } \\
\text { Consumers Purchased Via Online } \\
\text { Before MCO }\end{array}$ & Frequency & Percent \\
\hline Food & 107 & 57.2 \\
\hline Fashion & 145 & 77.5 \\
\hline Household & 93 & 49.7 \\
\hline Beauty \& Care & 75 & 40.1 \\
\hline Consumer Electronic & 61 & 32.6 \\
\hline Do It Yourself (DIY) & 33 & 17.6 \\
\hline Gardening & 6 & 3.2 \\
\hline Drug/Medicine & 19 & 10.2 \\
\hline Books/Magazine & 29 & 15.5 \\
\hline Games & 19 & 10.2 \\
\hline
\end{tabular}

Table 3: Category/Type of Products Consumers Purchased Via Online During MCO

\begin{tabular}{|c|c|c|}
\hline \begin{tabular}{lcr} 
Category/Type of & \multicolumn{2}{r}{ Products } \\
Consumers Purchased Via Online & $\begin{array}{l}\text { Via Ofore MCO } \\
\end{array}$
\end{tabular} & Frequency & Percent \\
\hline Food & 157 & 84 \\
\hline Fashion & 112 & 59.9 \\
\hline Household & 120 & 64.2 \\
\hline Beauty \& Care & 103 & 55.1 \\
\hline Consumer Electronic & 80 & 42.8 \\
\hline Do It Yourself (DIY) & 44 & 23.5 \\
\hline Gardening & 24 & 12.8 \\
\hline Drug/Medicine & 28 & 15 \\
\hline Books/Magazine & 45 & 24.1 \\
\hline Games & 29 & 15.5 \\
\hline
\end{tabular}


Table 4: Category/Type of Products Consumers Purchased Via Online 12 Months After MCO

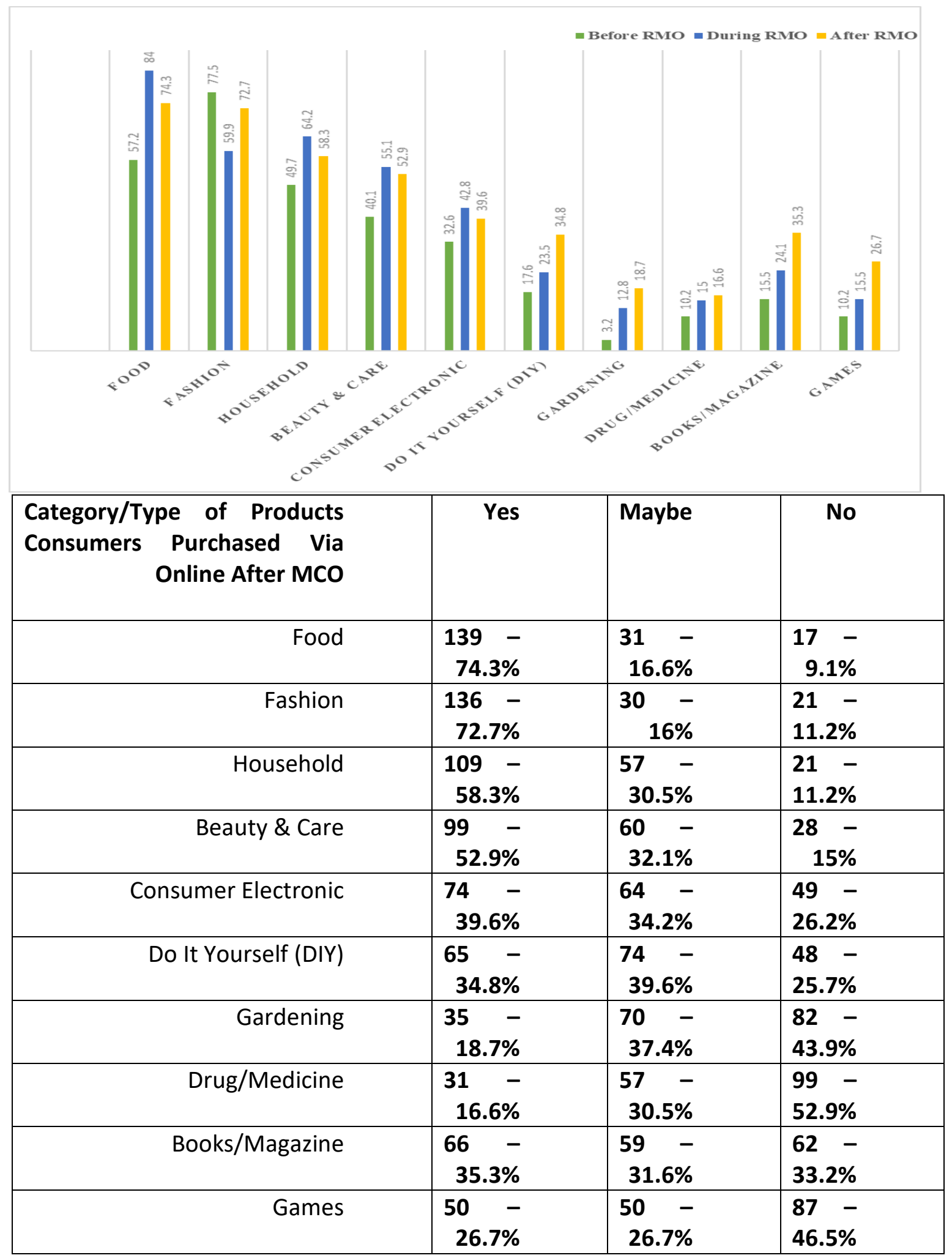

Diagram 1: The Category/Type of Products Consumers Purchased Via Online (Before, During and 12 Months After RMO) 
The graph above (Diagram 1) are the data gathered from Table 2, 3 and 4 on the category/type of products consumers purchased via online (before, during and 12 months after RMO). Based on the graph, food, household, beauty and care, and consumer electronic has same pattern where this type of products has been bought more during the RMO (84 per cent, 64.2 per cent, 55.1 per cent and 42.8 per cent). Differ for fashion, this type of product experienced in drop during the RMO from 77.5 per cent to 59.9 per cent before it rose again to 72.7 per cent 12 months after RMO. Do-it-yourself (DIY), gardening, drug/medicine, books/magazines and games are the types of products that continuously increasing even before, during and 12 months after RMO (17.6 to 34.8 per cent, 3.2 to 18.7 per cent, 10.2 to 16.6 per cent, 15.5 to 35.3 per cent and 10.2 to 26.7 per cent).

Table 5: Factors Influencing Consumers Purchased Via Online After RMO

\begin{tabular}{|r|r|c|}
\hline $\begin{array}{l}\text { Factors Influencing Consumers } \\
\text { Purchased Via Online After RMO }\end{array}$ & Frequency & Percent \\
\hline Convenience & 153 & 81.8 \\
\hline Save time & 145 & 77.5 \\
\hline Safety & 2 & 1.1 \\
\hline $\begin{array}{l}\text { Others Accessible } \\
\text { spreading (Cheaper, risk of } \\
\text { virus, goods from } \\
\text { other countries }\end{array}$ & 2 & $\mathbf{2}$ \\
\hline
\end{tabular}

Table 5 above shows the factors influencing consumers purchased via online after RMO with 81.8 per cent agree that online purchasing is convenience, followed by 77.5 per cent believed that online purchasing can save time. While, the total of 4.2 per cent of respondents choose to purchase online because of other factors such as cheaper goods, safety transaction and accessible source.

Table 6: Factors/Reasons Consumers Stop Purchased Via Online After RMO

\begin{tabular}{|c|c|c|}
\hline $\begin{array}{l}\text { Factors Influencing Consumers } \\
\text { Purchased Via Online After RMO }\end{array}$ & Frequency & Percent \\
\hline Support local business & $\mathbf{8 9}$ & $\mathbf{4 9 . 7}$ \\
\hline Generally, do not prefer online & $\mathbf{2 2}$ & $\mathbf{1 2 . 3}$ \\
\hline Prefer options in stores & $\mathbf{8 5}$ & $\mathbf{4 7 . 5}$ \\
\hline $\begin{array}{l}\text { Others (I need something } \\
\text { urgently, safety reasons for } \\
\text { electrical products) }\end{array}$ & 3 & 1.8 \\
\hline
\end{tabular}

In the other hand, as shown in Table 6, factors influencing consumers stop purchased via online after RMO are to support local business (49.7 per cent), preferences options available in store (47.5 per cent), respondents do not prefer online transaction (12.3 per cent) and other reasons such as urgency and safety reason generally with electric products (1.8 per cent). 
Table 7: Consumers Preferences for Online Payment Method After RMO

\begin{tabular}{|r|c|c|}
\hline Payment Method & Frequency & Percent \\
\hline $\begin{array}{r}\text { Mobile Application (EWallet, Shoppe } \\
\text { Coins, Grab Points) }\end{array}$ & 6 & 3.8 \\
\hline Credit/Debit Card & 25 & 13.4 \\
\hline Online Banking & 76 & 40.6 \\
\hline I Use All Online Payment Method & 79 & 42.2 \\
\hline
\end{tabular}

In Table 7, the online payment methods preferred by consumers are all online payment method (42.2 per cent), online banking (40.6 per cent), credit/debit card (13.4 per cent) and mobile application such as, e-Wallet, Shoppe Coins and Grab Points (3.8 per cent).

The study continues to investigates each factor influencing the preferred methods above to understand on how consumer generally choose their payment methods when they purchased online.

Table 8: Consumers Preferences for Mobile Application as Payment Method to Buy Products Through Online After RMO

\begin{tabular}{|r|r|r|}
\hline $\begin{array}{c}\text { Consumers Preferences for Mobile } \\
\text { Application as Payment Method to Buy } \\
\text { Products Through Online After Pandemic } \\
\text { Covid-19/Post Covid-19 }\end{array}$ & Frequency & \\
\hline Yes & 116 & 62.0 \\
\hline No & 17 & 9.1 \\
\hline Maybe & 54 & 28.9 \\
\hline
\end{tabular}

Table 9: Factors Influencing Consumers Preferences for Mobile Application as Payment Method to Buy Products Through Online After RMO

\begin{tabular}{|r|c|c|}
\hline $\begin{array}{l}\text { Factors Influencing Consumers } \\
\text { Preferences for Mobile Application as } \\
\text { Payment Method to Buy Products } \\
\text { Through Online After Pandemic Covid- } \\
\text { 19/Post Covid-19 }\end{array}$ & Frequency & \\
\hline Convenience & 75 & 39.9 \\
\hline Prefer cashless & 95 & 50.7 \\
\hline Time saving & 18 & 9.5 \\
\hline
\end{tabular}

According to Table 8, 62 per cent of respondents preferred to used mobile application as payment method to buy products through online after RMO because they prefer cashless with 50.7 per cent, 39.9 per cent believes mobile application is convenience and time saving with 9.5 percent (refer Table 9). 
Table 10: Consumers Preferences for Credit Card as Payment Method to Buy Products Through Online After RMO

\begin{tabular}{|r|r|r|}
\hline $\begin{array}{c}\text { Consumers Intention to Use Mobile } \\
\text { Application as Payment Method to Buy } \\
\text { Products Through Online After MCO }\end{array}$ & Frequency & Percent \\
\hline Yes & 129 & 69 \\
\hline No & 30 & 16 \\
\hline Maybe & 28 & 15 \\
\hline
\end{tabular}

Table 11: Factors Influencing Consumers Preferences for Credit Card as Payment Method to Buy Products Through Online After RMO

\begin{tabular}{|r|r|r|}
\hline $\begin{array}{r}\text { Factors Influencing Consumers } \\
\text { Preferences for Credit Card As Payment } \\
\text { Method To Buy Products Through Online } \\
\text { After Pandemic Covid-19/Post Covid-19 }\end{array}$ & Frequency & \\
\hline Convenience & 95 & 50.6 \\
\hline Prefer cashless & 77 & 41.0 \\
\hline Time saving & 16 & 8.3 \\
\hline
\end{tabular}

Meanwhile, Table 10 shows 69 per cent of respondents opts to choose credit card as payment method to buy products through online after RMO because its convenient ( 50.6 percent), they prefer cashless ( 41 per cent) and time saving ( 8.3 per cent). This can be seen from the Table 11.

Table 12: Consumers Preferences for Online Banking as Payment Method to Buy Products Through Online After RMO

\begin{tabular}{|r|r|r|}
\hline $\begin{array}{c}\text { Consumers Intention to Use Mobile } \\
\text { Application as Payment Method to Buy } \\
\text { Products Through Online After MCO }\end{array}$ & Frequency & Percent \\
\hline Yes & 171 & 91.4 \\
\hline No & 3 & 1.6 \\
\hline Maybe & 13 & 7.0 \\
\hline
\end{tabular}

Table 13: Factors Influencing Consumers Preferences for Online Banking as Payment Method to Buy Products Through Online After RMO

\begin{tabular}{|r|r|c|}
\hline $\begin{array}{l}\text { Factors Influencing Consumers } \\
\text { Preferences for Credit Card as Payment } \\
\text { Method to Buy Products Through Online } \\
\text { After Pandemic Covid-19/Post Covid-19 }\end{array}$ & Frequency & Percent \\
\hline Convenience & 109 & 58.2 \\
\hline Prefer cashless & 55 & 29.4 \\
\hline Time saving & 23 & 12.4 \\
\hline
\end{tabular}

As for online banking, 91.4 per cent of respondents (refer to Table 12) intended for it as payment method to buy products through online after RMO. By Table 13, the respondents 
believe by using online banking, it is convenient ( 58.2 per cent), cashless ( 29.4 per cent) and time saving (12.4 per cent).

\section{Conclusion}

As of conclusion, 12 attributes relating to consumer purchased via online have been established in this study. There are some changes identified with regards to consumer patterns in buying online of certain categories of products. All in all, the food-based product dominated the consumer intention regardless of any other phase and surprisingly, Do-ityourself (DIY), gardening, drug/medicine, books/magazines and games are the types of products that continuously increasing purchased by consumer via online after RMO. As of fashion-based product, the percentage of purchased via online is slightly lower compared to pre RMO as majority of consumer still prefer to buy these items in store might probably to avoid size and fitting issue.

This unfortunate event has created a big shift in purchasing behavior. Digital purchase is expected to become a norm and daily practice. However, with the rises of cases reported in Malaysia specifically, purchasing power, lifestyle, psychographic and others are expected to be different from today onwards. Therefore, further studies should be conducted as to have a better understanding in the consumption patterns especially among the younger generations. They are the Coronials that will shape the future nation's economy.

\section{References}

Arora, N., Robinson, K., Charm, T., Grimmelt, A., Ortega, M., Staack, Y., ... Yamakawa, N. (2020). Consumer Sentiment and Behavior Continue to Reflect the Uncertainty of the COVID-19 Crisis. Retrieved August 11, 2020, from https://www.mckinsey.com/business-functions/marketing-and-sales/our-insights/aglobal-view-of-how-consumer-behavior-is-changing-amid-covid-19

Bahtar, A. Z. (2019). The Influence of Mobile Environmental Cues on Purchasing Intention and Positive User-Generatad Content Spread in Instagram Context. Universiti Teknologi MARA. Retrieved from http://ir.uitm.edu.my/id/eprint/35016

Jones, K. (2020). COVID-19The Pandemic Economy: What are Shoppers Buying Online During COVID-19, from https://www.visualcapitalist.com/shoppers-buying-onlineecommerce-covid-19

Jung, H., Park, M., Hong, K., \& Hyun, E. (2016). The Impact of an Epidemic Outbreak on Consumer Expenditures: An Empirical Assessment for MERS Korea. Sustainability MDPI, (8), 454, 1-15.

Malaysian Communication and Multimedia Commission (MCMC). (2017). Internet users survey 2017: Statistical brief number twenty one. Malaysian Communication and Multimedia Commission. ISBN 1823- 2523

Pastore, A. (2020). Reports Predict Consumer Behavior in a Post-COVID-19 World. Retrieved August 5, 2020, from https://wwd.com/business-news/business-features/consumerbehavior-reports-predict-a-post-covid-world-1203562275/

PMO. (2020). The Prime Minister's Special Message on COVID-19 16 March 2020. Putrajaya, Malaysia. Retrieved from https://www.pmo.gov.my/2020/03/perutusan-khas-yabperdana-menteri-mengenai-covid-19-16-mac-2020/

Roy, D., Tripathy, S., Kar, S. K., Sharma, N., Verma, \& Kaushal., V. (2020). Study of knowledge, attitude, anxiety and perceived mental healthcare need in India population during 
Covid-19 pandemic. Asian Journal of Psychiatry, 51, pp.1-7. doi:10.1016/j.ajp.2020.102083

Davis, S. L. T. (2020). How Coronavirus Is Impacting Ecommerce.

Shyam, R., \& Abirami, A. (2020). Marketing in the Age of Corona Virus - Understanding the Consumer Mindset for Effective Marketing Strategies. Journal of Emerging Technologies and Innovative Research (JETIR). JETIR April 2020, Volume 7, Issue 4. pp. 1015 - 11021.

Standish, J., \& Bossi, M. (2020). How Will COVID-19 Change the Retail Consumer? Retrieved from www.accenture.com/research

Statista. (2020). Frequency of online purchases during COVID-19 pandemic Malaysia 2020. https://www.statista.com/statistics/1128935/malaysia-frequency-of-online-purchasecovid-19/

Syahirah, S. J. (2020). Over two-thirds of Malaysians now more comfortable shopping online after Covid-19. The edge markets. https://www.theedgemarkets.com/article/overtwothirds-malaysians-now-morecomfortable-shopping-online-after-covid19\%E2\%80\%94-stanchart

Tam, B. (2020). How COVID-19 Will Change Consumer Behavior + Purchase Patterns. Retrieved August 5, 2020, from https://www.hkstrategies.com/how-covid-19-willchange-consumer-behavior-purchase-patterns/

Tham, K. W., Dastane, O., Johari, Z., \& Ismail, N. (2019). Perceived Risk Factors Affecting Consumers' Online Shopping Behaviour. Journal of Asian FInance, Economics and Business, 6(4), 246-260. https://doi.org/dx.doi.org/10.2139/ssrn.3498766

Tucker, R. (2020). How Has Covid-19 Changed Consumer Behaviour. Retrieved August 11, 2020, from https://www.mixmove.io/blog/how-has-covid-19-changed-consumerbehaviour

United Nations. (2020). Pandemic has forever changed online shopping; UN-backed survey reveals. https://news.un.org/en/story/2020/10/1074982

WHO. (2020). Coronavirus Disease (COVID-19) in Malaysia. Retrieved August 5, 2020, from https://www.who.int/malaysia/emergencies/coronavirus-disease-(covid-19)-inmalaysia

Wold, S. (2020). How Covid-19 has Changed Shopper Behaviour. Retrieved August 5, 2020, from https://www.marketingweek.com/how-covid-19-has-changed-shopperbehaviour/

Zierlein, T., Garbe, C., Freesemann, M.-L., Naumann, L., \& Maag, V. (2020). Impact of the COVID-19 Crisis on Short and Medium term Consumer Behavior. 